\title{
ANALISIS PEMANFAATAN INSTAGRAM @DEARCATCALLERS.ID SEBAGAI MEDIA UNTUK MEMBENTUK KESADARAN MENGENAI ISU CATCALLING TERHADAP WANITA DI INDONESIA
}

\section{Monica Elvira}

Institut Komunikasi dan Bisnis LSPR, Jakarta, Indonesia

Email: monicaelvira23@gmail.com

\begin{abstract}
Abstrak
Salah satu fenomena dan isu pelecehan seksual yang sering terjadi adalah Catcalling. Korban Catcalling didominasi oleh wanita dan hal ini membuat mereka merasa tidak aman dan nyaman ketika berada di ruang publik. Oleh karena itu, perlu adanya edukasi dan kesadaran masyarakat dan hadirnya teknologi telah memungkinkan bagi seseorang atau organisasi untuk mengedukasi dan meningkatkan awareness melalui sosial media seperti Instagram, penelitian ini akan membahas akun Instagram @dearcatcallers.id dan bagaimana akun ini dapat mengedukasi dan meningkatkan kesadaran terhadap isu Catcalling di Indonesia melalui pengelolaan empat langkah dalam Media Model Praktis dan dipertajam dengan Social Information Processing. Hasil dari penelitian ini menunjukkan bahwa akun Instagram @dearcatcallers.id dapat mengedukasi dan meningkatkan kesadaran mengenai Catcalling melalui pemanfaatan fitur-fitur Instagram dan keempat aspek dalam Media Model Praktis dan aspek SIP secara konsisten menghasilkan tujuan yang ingin didapatkan akun ini dalam mengedukasi dan meningkatkan kesadaran akan isu Catcalling di Indonesia. Fitur profil dimanfaatkan oleh @dearcatcallers.id dalam mengedukasi secara dasar mengenai apa itu Catcalling. Fitur Pengikut digunakan sebagai fitur yang menunjukkan bahwa orang-orang yang mengikuti akun ini memiliki ketertarikan akan isu pelecehan seksual dan Catcalling. Konten yang diposting dan fitur keterangan untuk menyampaikan pesan. Fitur like termasuk salah satu bentuk interaksi. Balasan komentar yang didapat dari pemilik akun @dearcatcallers.id memiliki tujuan untuk meluruskan pemikiran pengirim komentar yang salah atau memberikan edukasi dan meningkatkan kesadaran akan isu yang dibahas. Adapun hambatan yang ditemui pemilik akun serta upaya untuk mengatasi hambatan tersebut yaitu adanya keterbatasan dalam memposting dan berbicara mengutarakan opini karena adanya UU ITE serta dari segi pemilihan konten.
\end{abstract}

Kata Kunci: model praktik media; kesadaran; pelecehan seksual verbal (catcalling); akuninstagram @Dearcatcallers.id

\section{Abstract}

The fact that most Catcalling victims are female makes them feel insecure and uncomfortable whenever they are in public spaces. Therefore, this issue needs to be addressed with the education and awareness regarding Catcalling, to make people

$\begin{array}{ll}\text { How to cite: } & \text { Elvira. M (2021) Analisis Pemanfaatan Instagram @Dearcatcallers.id Sebagai Media untuk Membentuk } \\ & \text { Kesadaran Mengenai Isu Catcalling Terhadap Wanita Di Indonesia. Syntax Literate: Jurnal Ilmiah } \\ & \text { Indonesia, 6(10). http://dx.doi.org/10.36418/ Syntax-Literate.v6i10.4365 } \\ & \text { 2548-1398 } \\ \text { E-ISSN: } & \text { Ridwan Institute }\end{array}$


Analisis Pemanfaatan Instagram @ Dearcatcallers.id Sebagai Media Untuk Membentuk Kesadaran Mengenai Isu Catcalling Terhadap Wanita Di Indonesia

understand that Catcalling should be stopped. This study about the Instagram account@dearcatcallers.idin how thesocialmediaInstagram @dearcatcallers.id educates and raises awareness about the issue of Catcalling in Indonesia through managing the four steps in the Media Practice Model and Social Information Processing as well as efforts and obstacles in managing it. The results of this study indicate that the Instagram account @dearcatcallers.id can educate and raise awareness about Catcalling through the use of Instagram features and all four aspects in the Media Practice Model and Social Information Processing aspects consistently produce the objectives that this account wants to obtain in educating and raising awareness of the Catcalling issue in Indonesia. The profile feature is usedby@dearcatcallers.id in basic education about what Catcalling is. The Followers feature is used as a feature to show that people who follow this account have an interest in sexual harassment and catcalling issues. Posted content and caption features to convey messages. The like feature is one form of interaction. Replies to comments obtained from the owner of the @ dearcatcallers.id account have the aim of correcting the thoughts of the wrong commenter or providing education and raising awareness of the issues discussed. The obstacles encountered by account owners and efforts to overcome these obstacles are the limitations in posting and speaking to express opinions because of the ITE Law and in terms of content selection.

Keywords: media practice model; awareness; verbal sexual harassment (catcalling); akun instagram@Dearcatcallers.id

Received: 2021-09-20; Accepted: 2021-10-05; Published: 2021-10-20

\section{Pendahuluan}

Pelecehan seksual dapat terjadi dimanapun dan kapanpun serta tidak mengenal latar belakang dan usia. Menurut Naskah Akademik Rancangan Undang-Undang Tentang Penghapusan Kekerasan Seksual oleh KOMNAS Perempuan dalam Masyarakat Pemantau Peradilan Indonesia Fakultas Hukum Universitas Indonesia (Florence, 2017), pelecehan seksual merupakan tindakan lewat sentuhan fisik maupun non fisik seperti siulan, main mata, ucapan bernuansa seksual, mempertunjukkan atau mempertontonkan materi yang berbau pornografi dan keinginan seksual, gerakan atau isyarat yang bersifat seksual, sehingga mengakibatkan pihak lainnya merasa tidak nyaman, tersinggung, dan direndahkan martabatnya, dan mungkin sampai menyebabkan masalah keselamatan dan kesehatan. Dari pengertian tersebut dapat dipastikan bahwa pelecehan seksual tidak hanya lewat sentuhan fisik namun dapat berupa verbal, visual, dan tulisan.

Korban kekerasan dan pelecehan seksual didominasi oleh perempuan karena perempuan masih menjadi bagian dari kelompok rentan kekerasan seksual di Indonesia. Menurut hasil survei Kementerian Pemberdayaan Perempuan dan Perlindungan Anak (Tuasikal \& Patria, 2019), satu dari tiga perempuan berusia 15-64 tahun pernah mengalami kekerasan fisik dan pelecehan seksual. 
Salah satu bentuk pelecehan seksual yang sering terjadi di ruang publik dan membuat perempuan menjadi merasa tidak aman dan nyaman adalah pelecehan seksual secara verbal atau yang biasa disebut "Catcalling" (Hidayat \& Setyanto, 2020). Tindakan Catcalling di Indonesia sudah masuk ke dalam kategori tindakan pelecehan seksual (secara verbal).

Catcalling merupakan suatu tindakan yang berupa siulan, sapaan, atau bahkan komentar yang bersifat menggoda dan merupakan salah satu bentuk pelecehan seksual yang terjadi di tempat atau ruang publik axford Learner's Dictionaries, 2018). "Perbuatan seperti bersiul dan mencolek/menyentuh bagian tubuh tertentu wanita termasuk ke dalam tindakan pelecehan seksual dan sayangnya tidak semua orang memahaminya" (Herdiansyah, 2016).

Isu Catcalling yang semakin meluas dan banyak korban yang membagikan ceritanya di media sosial (El-Yana, 2021), maka munculah akun ini yang menampung cerita-cerita dari warga sosial media dan mengedukasi serta membentuk pemahaman atau penerangan akan pemahaman masyarakat yang keliru dan cenderung menyalahkan korban pelecehan seksual terutama dalam isu Catcalling melalui media sosial Instagram.

Akun Instagram @dearcatcallers.id telah memiliki pengikut sebanyak 69,2 ribu pengikut per bulan Juni tahun 2019. Akun ini bertujuan untuk memberikan edukasi dan meningkatkan kesadaran masyarakat luas mengenai pelecehan seksual terhadap kaum wanita khususnya Catcalling yang sering terjadi.

Peneliti memilih Instagram @ dearcatcallers.id sebagai penelitian karena diantara enam akun Instagram yang membahas mengenai Catcalling di Indonesia, hanya akun @ dearcatcallers.id yang memiliki konten yang terus diperbaharui sejak pembuatan akunnya di tanggal 12 Oktober 2017, serta mengajak pengikutnya untuk terus berinteraksi. Jumlah pengikutnya juga lumayan banyak diantara akun-akun lain yang membahas mengenai isu Catcalling di Indonesia dan hanya akun @dearcatcallers.id yang mendapat banyak umpan balik dari pengikutnya sehingga terjadi interaksi aktif antara pengikut dan pemilik akun. Peneliti ingin meneliti bagaimana cara akun ini untuk dapat mengedukasi dan membentuk kesadaran mengenai isu Catcalling melalui pemanfaatan fitur-fitur di Instagram serta melalui konten yang diunggah.

Sejauh ini, peneliti berhasil mengumpulkan data akun-akun yang membahas mengenai isu catcalling di Instagram khususnya di wilayah Indonesia sebanyak 6 akun.

Tabel 1

Perbandingan Pengikut Akun Instagram yang Membahas Mengenai Isu Catcalling di Indonesia

\begin{tabular}{lllll}
\hline Nama Akun & $\begin{array}{l}\text { Nama } \\
\text { Founder }\end{array}$ & $\begin{array}{l}\text { Tanggal Postingan } \\
\text { Pertama }\end{array}$ & $\begin{array}{l}\text { Jumlah } \\
\text { Postingan }\end{array}$ & $\begin{array}{l}\text { Jumlah } \\
\text { Pengikut } \\
\text { (Followers) }\end{array}$ \\
\hline @againtscatcalling & $\begin{array}{l}\text { Tidak } \\
\text { diketahui }\end{array}$ & 17 Mei 2018 & 64 & 714 \\
\hline
\end{tabular}


Analisis Pemanfaatan Instagram @ Dearcatcallers.id Sebagai Media Untuk Membentuk Kesadaran Mengenai Isu Catcalling Terhadap Wanita Di Indonesia

\begin{tabular}{lllll}
\hline @stttopcatcalling & $\begin{array}{l}\text { Annisaa } \\
\text { Maryama }\end{array}$ & 26 Desember 2017 & 5 & 135 \\
\hline @ stopcatcalling_id & $\begin{array}{l}\text { Tidak } \\
\text { diketahui }\end{array}$ & 25 September 2019 & 9 & 30 \\
\hline @ hentikancatcalling & $\begin{array}{l}\text { Tidak } \\
\text { diketahui }\end{array}$ & 20 Desember 2017 & 6 & 28 \\
\hline @jangancatcalling & $\begin{array}{l}\text { Tidak } \\
\text { diketahui }\end{array}$ & 4 Desember 2018 & 51 & 13 \\
\hline @ dearcatcallers.id & $\begin{array}{l}\text { Monica } \\
\text { Devina }\end{array}$ & 13 Oktober 2017 & 818 & 66.100 \\
\hline
\end{tabular}

Sumber: Against Catcalling, (sttt)op Catcall !, STOP CATCALLING!, Hentikan Catcalling, NO CATCALLING FOR US!, Data Olahan Peneliti, 2019.

Penelitian ini meneliti mengenai akun yang ada di media sosial Instagram karena informasi yang disebarkan akan berlanjut terus menerus tanpa batas waktu dan tidak tergantung pada tempat dan jarak serta dapat memberikan kesadaran (awareness) yang tinggi serta memancing orang untuk membagikan ceritanya dibanding kampanye di jalan yang hanya dilakukan satu atau beberapa kali (Prihatiningsih, 2017).

Isu Catcalling juga ditujukan khususnya bagi wanita yang sering mengalami Catcalling (Shopiani, Wilodati, \& Supriadi, n.d.). Instagram juga memiliki banyak fitur yang mempermudah pengguna untuk saling berinteraksi dan mudah untuk membagikan postingan yang diunggah sehingga informasi tersebut dapat dijangkau oleh banyak orang.

Instagram mengedepankan tampilan foto dan video secara visual. Indera penglihatan dan pendengaran banyak digunakan di media sosial Instagram. Era informasi digital saat ini membuat visual diminati karena banyaknya informasi yang berkembang (Miles, 2013). Berdasarkan elaborasi dari peristiwa tersebut, maka rumusan masalah yang dipilih oleh peneliti yang diharapkan dapat dijawab dengan penelitian ini yaitu bagaimana akun Instagram @dearcatcallers.id mengedukasi dan membentuk kesadaran terhadap isu Catcalling di Indonesia dan apa cara yang dilakukan akun@dearcatcallers.id dalam mengedukasi dan membentuk kesadaran terhadap isu Catcalling di Indonesia?

Atas dasar dari rumusan masalah yang telah ditentukan oleh peneliti, tujuan adanya penelitian ini, antara lain: (1) Untuk meneliti bagaimana dan dengan cara apa akun Instagram @dearcatcallers.id dalam mengedukasi masyarakat mengenai isu Catcalling. (2) Mengetahui hambatan dan upaya akun Instagram @dearcatcallers.id dalam membentuk dan mengedukasi banyak pihak mengenai pelecehan seksual terutama mengenai Catcalling yang terjadi di Indonesia. 


\section{Metode Penelitian}

Penelitian ini menggunakan metodologi deskriptif kualitatif karena peneliti ingin memahami lebih dalam secara deskriptif tentang akun @dearcatcallers.id dalam membentuk isu Catcalling melalui media sosial Instagram yang menjadi bagian dari fenomena yang terjadi di Indonesia. (Suliyanto \& MM, 2017) mendefinisikan metode penelitian deskriptif kualitatif sebagai metode yang digunakan oleh peneliti untuk menemukan pengetahuan atau teori terhadap penelitian yang diteliti pada satu waktu tertentu.

Melalui metode ini, penulis mencoba untuk mengungkapkan mengenai tujuan, hambatan, serta upaya-upaya yang dilakukan oleh akun Instagram @ dearcatcallers.id sebagai akun yang memanfaatkan media sosial Instagram untuk membentuk isu mengenai Catcalling melalui uraian, ucapan, tulisan, atau perilaku yang dapat diamati. Analisis penelitian akan dideskripsikan melalui kata-kata secara deskriptif. Metode penelitian kualitatif deskriptif menggunakan penelitian Bahasa Indonesia untuk mengumpulkan data dan menggambarkannya secara alamiah.

Penelitian ini berfokus kepada pemanfaatan Instagram @dearcatcallers.id dalam membentuk kesadaran mengenai isu Catcalling dengan mengacu pada 4 langkah yang ada di teori Media Model Praktis yaitu:

\section{Tabel 2}

Fokus Penelitian

\begin{tabular}{|c|c|c|c|}
\hline $\begin{array}{c}\text { Objek } \\
\text { Penelitian }\end{array}$ & Langkah & Evidensi & Metode \\
\hline \multirow{3}{*}{$\begin{array}{l}\text { Instagram } \\
\text { @ dearcatcallers. } \\
\text { id dalam membuat } \\
\text { aku tersebut dan } \\
\text { membuat konten } \\
\text { mengenai pelecehan } \\
\text { seksual yang terjadi } \\
\text { sehingga membentuk } \\
\text { kesadaran akan isu } \\
\text { pelecehan seksual } \\
\text { terutama mengenai } \\
\text { isu Catcalling di } \\
\text { masyarakat melalui } \\
\text { media Instagram. }\end{array}$} & $\begin{array}{l}\text { 1. Identitas(Identity) } \\
\text { (melihat dari pemenfaatan fitur } \\
\text { profil, postingan, keterangan } \\
\text { postingan, cerita) }\end{array}$ & $\begin{array}{l}\text { identitas diri (identity) } \\
\text { dalam penelitian ini } \\
\text { adalah identitas akun } \\
\text { @dearcatcallers.id } \\
\text { sebagai akun yang } \\
\text { ingin membentuk dan } \\
\text { mengedukasi } \\
\text { masyarakat } \\
\text { mengenai luas } \\
\text { Catcalling }\end{array}$ & $\begin{array}{l}\text { Wawancara } \\
\text { pribadi }\end{array}$ \\
\hline & $\begin{array}{l}\text { 2. Seleksi(Selection) } \\
\text { (melihat dari pemilihan media } \\
\text { sosial Instagram) }\end{array}$ & $\begin{array}{lr}\text { Media yang } & \text { dipilih } \\
\text { adalah media } & \text { sosial } \\
\text { Instagram } & \text { karena } \\
\text { targetnya } & \text { yang } \\
\text { kebanyakan } & \text { adalah } \\
\text { wanita berusia } & 18-30 \\
\text { tahun } & \end{array}$ & $\begin{array}{l}\text { Wawancara } \\
\text { pribadi }\end{array}$ \\
\hline & $\begin{array}{l}\text { 3. Interaksi(Interaction) } \\
\text { dan Social Information } \\
\text { Processing } \\
\text { (melihat dari pemanfaatan fitur }\end{array}$ & $\begin{array}{l}\text { Terjadilah interaksi } \\
\text { antara pemilik akun dan } \\
\text { pengikut atau pengguna } \\
\text { Instagram dan beberapa }\end{array}$ & $\begin{array}{l}\text { Wawancara } \\
\text { pribadi }\end{array}$ \\
\hline
\end{tabular}




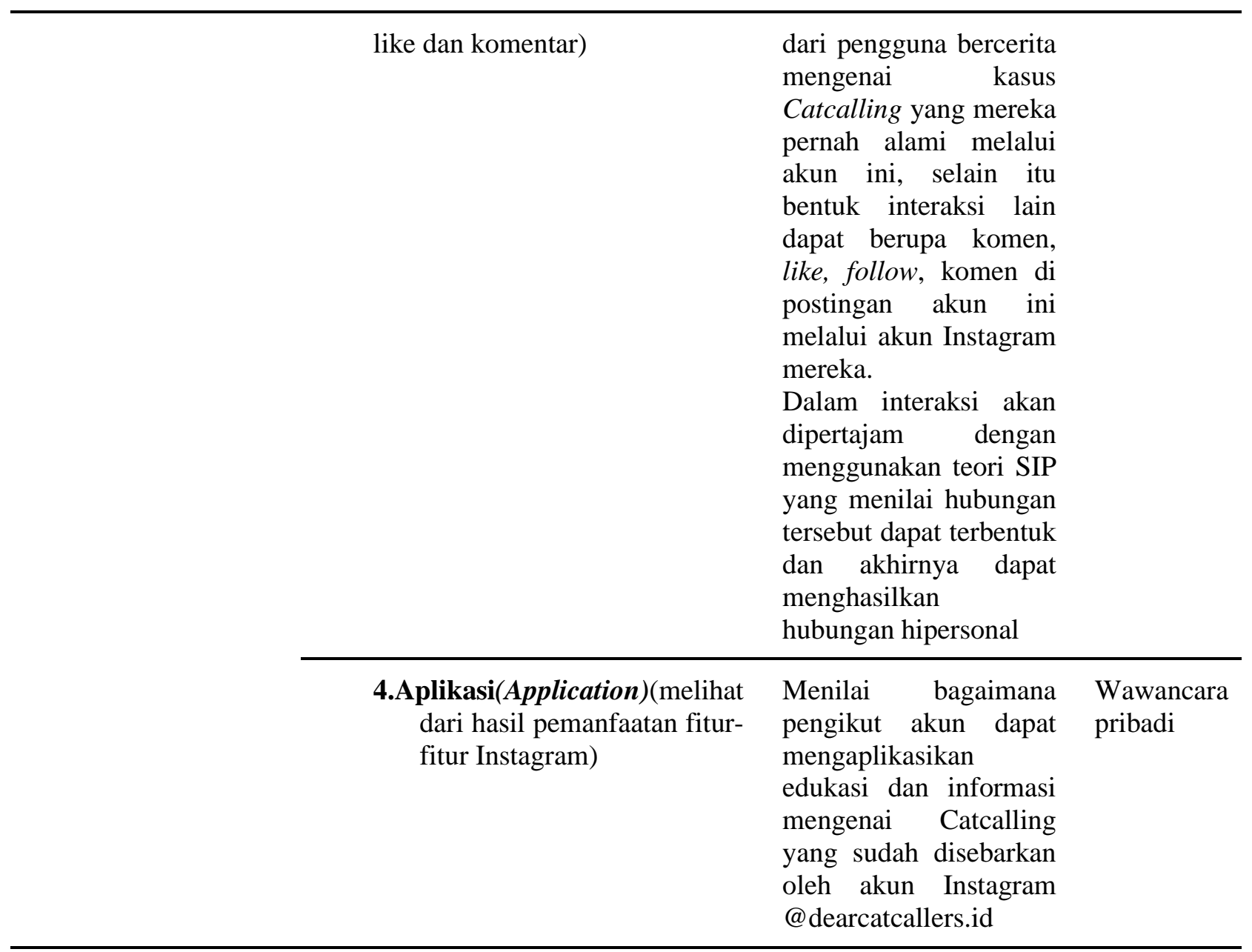

Sumber: Steel \& Brown, 1995; data olahan peneliti, 2019.

\section{Hasil dan Pembahasan}

\section{A. Target Publik Akun Instagram @Dearcatcallers.id}

Akun Instagram @dearcatcallers.id memiliki target publik yaitu pengguna Instagram khususnya wanita yang berusia 18-30 tahun. Akun ini menargetkan wanita karena korban-korban Catcalling yang didominasi oleh wanita. Awal yang harus dilakukan adalah mengedukasi korban terlebih dahulu agar korban paham bahwa pelecehan secara verbal dapat terjadi dan disebut sebagai isu Catcalling lalu korban dapat mengutarakan pengalaman mereka melalui akun ini dan setelah itu, akun ini membagikan pengalaman korban sehingga dapat meningkatkan kesadaran akan isu ini kepada pengguna Instagram secara lebih luas.

\section{B. Positioning Akun Instagram @Dearcatcallers.id}

Dalam mengedukasi dan meningkatkan awareness mengenai pelecehan seksual secara verbal (Catcalling), akun Instagram @dearcatcallers.id juga melakukan positioning akun tersebut di Instagram. Positioning merupakan tindakan dalam merancang tawaran dan citra organisasi sehingga menempati posisi yang khas di dalam benak sasarannya (Kotler \& Keller, 2016). Tujuan dalam melakukan positioning untuk memosisikan sebuah organisasi dari cara aspek tingkah laku, cara 
berbicara kepada target, dan sebagainya. Organisasi yang dimaksud dalam penelitian ini adalah akun Instagram @dearcatcallers.id.

Akun Instagram @dearcatcallers.id memosisikan diri sebagai akun yang mengedukasi dan meningkatkan awareness mengenai isu Catcalling serta menjadi ruang aman bagi para korban yang mau bercerita mengenai pengalamannya sebagai korban Catcalling. Hal ini dilakukan oleh akun ini karena adanya perhatian khusus pemilik akun mengenai isu Catcalling yang sering terjadi di ruang publik.

Pemilik akun mengatur dan mengelola akun Instagram @dearcatcallers.id sesuai dengan positioning yang dilakukan sehingga dapat mencapai langkah-langkah yang tepat dan para pengikut serta target audience akun ini dapat paham bahwa akun ini merupakan akun dalam meningkatkan kesadaran dan edukasi mengenai isu Catcalling.

Pengelolaan aspek langkah-langkah dari teori Media Model Praktis, yaitu langkah identitas, seleksi, interaksi, dan aplikasi, dilakukan melalui penggunaan fitur-fitur di Instagram seperti adalah profil, pengikut dan mengikuti, postingan yang berupa foto atau video, keterangan gambar atau video yang diposting, cerita Instagram tanda suka (like) dan, komentar.

\section{Tujuan Akun Instagram @Dearcatcallers.id}

Akun Instagram @dearcatcallers.id memiliki tujuan untuk mengedukasi dan meningkatkan kesadaran akan isu Catcalling kepada masyarakat agar paham bahwa Catcalling merupakan salah satu bentuk pelecehan yang seharusnya dihentikan dan tidak dinormalisasi.

Pemilik akun mengutarakan bahwa tujuan akhir dari akun Instagram @ dearcatcallers.id setelah mengedukasi dan meningkatkan kesadaran adalah mengajak masyarakat untuk melawan isu Catcalling.

Oleh karena itu, untuk mencapai tujuan yang diinginkan oleh pemilik akun melalui akun Instagram @dearcatcallers.id perlu dilakukan positioning terlebih dahulu agar akun ini dapat dengan baik dan tepat dalam menyampaikan pesan edukasi dan meningkatkan kesadaran masyarakat akan isu Catcalling.

\section{Temuan Penelitian}

Peneliti telah melakukan penelitian terhadap bagaimana akun Instagram @ dearcatcallers.id dalam mengedukasi dan membentuk kesadaran terhadap isu Catcalling di Indonesia dan dilakukan melalui cara apa. Peneliti telah melakukan wawancara terhadap narasumber dan mengobservasi akun Instagram @ dearcatcallers.id sehingga sudah memperoleh data mengenai akun Instagram @ dearcatcallers.id dalam melakukan kegiatannya untuk mencapai tujuan sebagai akun yang mengedukasi dan meningkatkan kesadaran mengenai isu Catcalling.

Dalam mencapai tujuan yang diinginkan oleh akun Instagram @ dearcatcallers.id sebagai akun yang mengedukasi dan meningkatkan kesadaran masyarakat akan isu Catcalling, maka akun ini mengelola aspek-aspek yang terdapat dalam teori Media Model Praktis yang terdiri dari langkah identitas, seleksi, interaksi yang kemudian lebih lanjut dibahas dengan menggunakan teori Social Information 
Processing (SIP), serta aplikasi untuk tujuan penelitian yaitu mempelajari bagaimana akun tersebut dapat mengedukasi dan meningkatkan kesadaran masyarakat mengenai isu Catcalling dan apa cara yang dilakukan untuk melakukan hal tersebut. Dalam pengelolaannya untuk mencapai langkah-langkah tersebut, akun ini memanfaatkan berbagai fitur-fitur yang terdapat di media sosial Instagram.

Fitur-fitur tersebut adalah profil, pengikut dan mengikuti, postingan yang berupa foto atau video, keterangan gambar atau video yang diposting, cerita Instagram tanda suka (like)dan, komentar. Berikut adalah hasil yang penelitian berdasarkan hasil evidensi tersebut.

\section{E. Profil (Profile)}

Fitur Instagram yang memiliki daya tarik utama adalah profil. Profil dapat menjelaskan secara detail kepada para pengguna lainnya mengenai identitas akun yang bersangkutan. Fitur profil dapat mengedukasi secara dasar mengenai apa itu Catcalling dan tujuan dasar akun ini. Ketika membuka halaman awal Instagram, maka yang muncul pertama kali adalah halaman utama pengguna yaitu profil. Fitur profil menampilkan foto profil, bio, dan postingan-postingan akun, jumlah pengikut dan mengikuti Instagram tahun 2019.

\section{F. Pengikut dan Mengikuti (Followers and Following)}

Pengikut (followers) dan mengikuti (following) merupakan hal yang pasti ada di sosial media Instagram dan merupakan bagian yang penting untuk mengukur sebesar apa akun Instagram telah memperoleh target publik yang berhasil dituju. Setiap pengguna dapat menjadi pengikut (followers) suatu akun atau memiliki pengikut dan mengikuti (following) akun yang diinginkan. Sesama pengguna dapat melihat kiriman atau postingan sesama, mengomentari, dan memberi like Instagram tahun 2019.

Pada periode penelitian September 2019 sampai dengan Februari 2020 terdapat jumlah pengikut akun Instagram @dearcatcallers.id sebanyak 66,1 ribu dan naik menjadi 69,1 ribu pengikut di bulan Mei 2020. Terdapat peningkatan sebanyak 3 ribu pengikut dalam 9 bulan. Pada tanggal 25 Mei 2020, jumlah pengikut akun Instagram @ dearcatcallers.id naik sebesar seratus pengikut sehingga total pengikut akun ini adalah 69,2 ribu pengikut.

Jumlah pengikut serta latar belakang demografi maupun usia pegikut tidak dapat diatur oleh pemilik akun karena setiap pengguna memiliki hak bebas untuk mengikuti akun Instagram yang diinginkan. Berbeda halnya dengan fitur mengikuti. Dalam fitur following atau mengikuti ini, setiap pemilik akun Instagram dapat mengontrol akun apa yang ingin diikuti. Akun Instagram @ dearcatcallers.id hanya mengikuti akun-akun komunitas maupun akun pribadi yang menurut pemilik akun merupakan akun yang memiliki tema pembahasan yang sama.

Pada periode penelitian September 2019 sampai dengan Februari 2020 terdapat jumlah mengikuti sebanyak 210 akun Instagram lalu jumlah mengikuti naik sebanyak 5 akun sehingga total mengikuti di akun Instagram @ dearcatcallers.id menjadi mengikuti 215 akun pada bulan Mei 2020. 


\section{G. Postingan Foto dan Video (Photo and Video Posts)}

Pemilik akun Instagram dapat dengan bebas untuk memposting atau mengunggah foto atau video pada akunnya. Foto atau video yang ingin diposting dapat diambil langsung melalui kamera Instagram atau melalui galeri yang ada di telepon genggam pengguna (Manovich, 2017). Pengguna dapat memposting maksimal 10 foto atau video dalam satu postingan yang diunggah Instagram tahun 2019.

Postingan yang diunggah oleh akun Instagram @dearcatcallers.id membahas mengenai kasus pelecehan seksual secara general dan Catcalling, membagikan cerita mengenai pelecehan seksual yang dialami pengikut akun Instagram @ dearcatcallers.id sehingga dapat menjadi ruang bicara yang aman untuk korban, serta memposting poster acara yang berhubungan dengan tema pelecehan seksual atau women empowerment. Jenis postingan yang diposting dibagi menjadi tiga yaitu postingan berupa foto, video, dan gabungan antara foto dan video yang disertai dengan keterangan foto atau video berupa tulisan (caption). Selama periode penelitian dari bulan September 2019 sampai bulan Mei 2020, akun Instagram @ dearcatcallers.id telah memposting sebanyak 364 postingan diantaranya 217 foto, 116 video, dan 31 postingan berupa beberapa foto dan video.

\section{H. Cerita Instagram (Story)}

Cerita atau Instagram Stories juga termasuk unggahan yang berbentuk foto atau video yang dilakukan oleh pengguna Instagram (Karimkhani, Connett, Boyers, Quest, \& Dellavalle, 2014). Namun, bedanya postingan dengan Instagram Stories adalah foto dan video tersebut akan menghilang dalam waktu 24 jam namun postingan cerita dapat disimpan di akun profil sebagai sorotan cerita yang dapat dilihat kembali. Untuk melihat cerita Instagram suatu akun, dapat dilihat melalui dua tempat, yaitu di profil pengguna dan di bagian atas kabar Instagram tahun 2019).

Pemilik akun Instagram @dearcatcallers.id juga memanfaatkan fitur cerita Instagram dalam mengedukasi dan meningkatkan kesadaran masyarakat mengenai isu Catcalling.

\section{Tanda Suka (Like)}

Fitur like memiliki fungsi yang menandakan bahwa pengguna Instagram tersebut menyukai postingan gambar atau video yang telah diunggah oleh pengguna Instagram yang lain Instagram tahun 2019 (Mattern, 2016).

Like termasuk salah satu bentuk interaksi yang terjadi dalam sebuah akun di postingan yang telah diunggah oleh akun tersebut dan hal ini berlaku juga pada akun Instagram @dearcatcallers.id. Interaksi like merupakan sebuah umpan balik atau feedback dari pengikut akun tersebut. Berdasarkan socialblade.com, pada 364 postingan yang telah diunggah oleh akun @dearcatcallers.id terhitung dari bulan September 2019 hingga bulan Mei 2020, terdapat rata-rata like sebanyak 1,6 ribu likes.

Interaksi like yang didapat pada setiap postingan foto atau video yang diunggah oleh akun Instagram @ dearcatcallers.id tidak dapat diatur oleh pemilik 
akun karena like merupakan komunikasi satu arah dari pengikut akun kepada akun Instagram @ dearcatcallers.id. Walaupun tidak dapat diatur, like merupakan interaksi melalui postingan berupa umpan balik dari pengguna Instagram maupun pengikut akun yang menunjukkan bahwa mereka menyukai, setuju, dan mengerti atas informasi edukasi yang sudah disebarkan melalui postingan yang diunggah. Hal tersebut dapat diukur, dilihat, dan memberikan informasi mengenai persepsi pengikut kepada akun tersebut.

\section{J. Komentar Postingan (Comment)}

Fitur komentar dapat berupa teks yang dikirimkan oleh pengguna Instagram atau pengikut akun Instagram serta dapat dilihat oleh pengguna Instagram lainnya (Moreau, 2018). Komentar tersebut juga dapat dibalas, di like, atau dihapus Instagram tahun 2019. Komentar dapat dikirimkan dan dilihat pada setiap postingan foto atau video termasuk dalam postingan akun Instagram @dearcatcallers.id, pemanfaatan fitur komentar untuk membantu meningkatkan edukasi dan kesadaran mengenai isu pelecehan seksual dan Catcalling. Postingan yang diunggah akun Instagram @dearcatcallers.id dapat dikirimkan komentar oleh pengguna Instagram lainnya atau pengikut akun tersebut. Berdasarkan socialblade.com, jumlah rata-rata komentar pada postingan akun Instagram @ dearcatcallers.id periode penelitian bulan September sampai dengan Mei 2020, adalah sebanyak 22,7 komentar pada setiap kiriman.

Pada fitur komentar, dapat terjadi interaksi dua arah antara audience dengan pemilik akun Instagram @dearcatcallers.id. Balasan komentar yang didapat dari pemilik akun @dearcatcallers.id memiliki tujuan untuk meluruskan pemikiran pengirim komentar yang salah atau memberikan edukasi dan meningkatkan kesadaran akan isu yang dibahas dalam postingan. Namun komentar yang terdapat dalam postingan akun Instagram @ dearcatcallers.id tidak selalu dibalas oleh pemilik akun karena banyaknya komentar yang ada dan ada beberapa komentar yang sensitif atau komentar tersebut memang tidak perlu dibalas. Interaksi-interaksi yang sudah dijelaskan oleh pemilik akun dan dikonfirmasi oleh narasumber pendukung kemudian diteliti lebih lanjut melalui teori Social Information Processing.

Langkah Interaksi Dinilai Lebih Lanjut Melalui Teori SIP (Social Information Processing). Langkah interaksi yang terdapat dalam teori Media Model Praktis kemudian dipertajam dengan menggunakan teori SIP (Social Information Processing). Interaksi yang terjadi melalui akun Instagram @ dearcatcallers.id sesuai dengan unsur konsep media sosial yang memiliki komunikasi dua arah yaitu interaksi dengan sesama pemilik akun Instagram. Instagram sebagai media berbasis internet yang memungkinkan pengguna berkesempatan untuk saling berinteraksi dan mempresentasikan diri, baik secara seketika ataupun tertunda, dengan khalayak luas yang mendorong nilai dari user-generated content (konten yang dihasilkan dari user atau pengguna dalam hal ini adalah konten postingan di akun Instagram @ dearcatcallers.id) dan persepsi interaksi dengan orang lain (Carr \& Hayes, 2015). 
Hubungan hipersonal terbangun dan terjalin antara pemilik akun @ dearcatcallers.id sebagai pengirim pesan dengan penerima pesan yaitu pengikut akun dan pengguna Instagram lainnya. Pemilik akun @ dearcatcallers.id membangun kesan positif melalui identitas dan tujuan yang sudah dibentuk dan melalui pemanfaatan fitur-fitur Instagram sampai mendapatkan interaksi dan umpan balik dari orang-orang yang sudah like dan komentar di postingan akun tersebut.

\section{K. Langkah Aplikasi}

Langkah aplikasi adalah langkah akhir dalam Media Model Praktis yang mengidentifikasi bagaimana audience mengaplikasikan hasil yang sudah didapat berdasarkan asupan informasi dan interaksi yang diperoleh (Steele \& Brown, 1995).

Langkah ini didapatkan dari hasil memanfaatkan fitur-fitur seperti profil, pengikut dan mengikuti, postingan gambar atau video, keterangan postingan, cerita Instagram, like dan komentar. Penelitian ini bertujuan untuk mempelajari bagaimana akun Instagram @dearcatcallers.id dalam mengedukasi dan membentuk kesadaran terhadap isu Catcalling di Indonesia dan dilakukan melalui cara apa.

Hambatan yang ditemui oleh pemilik akun pada langkah aplikasi terjadi jika pengikut atau pengguna Instagram yang sudah membaca postingan masih belum paham sehingga tidak mendapatkan efek tertentu dan tidak dapat mengaplikasikan edukasi tersebut ke kehidupan mereka. Sehingga pemilik akun mengupayakan untuk meningkatkan kualitas postingan dan mempertajam maksud pesan namun tetap pada pembahasan tema yang dibahas oleh akun ini agar semua orang dapat memahami pesan yang ingin disampaikan oleh akun ini.

Akun ini sudah mengedukasi dan meningkatkan kesadaran akan isu Catcalling dengan cara memanfaatkan fitur-fitur Instagram sehingga hasilnya adalah audience atau pengikut dapat mengaplikasikan edukasi yang ada di akun ini ke kehidupannya masing-masing walaupun hasil aplikasi tiap pengikut dan interpretasinya yang berbeda.

\section{Hambatan dan Upaya}

Dalam menjalankan tujuan untuk mengedukasi dan meningkatkan kesadaran akan isu Catcalling sehingga mencapai langkah-langkah dalam Media Model Praktis, terdapat beberapa hambatan yang dirasakan oleh pemilik akun Instagram @ dearcatcallers.id dan upaya yang dilakukan ketika memanfaatkan fitur-fitur Instagram adalah sebagai berikut:

a. Hambatan dan upaya pada langkah identitas

Monica Devina merasa bahwa dalam menggunakan Instagram, berarti ia dapat dengan bebas memposting dan menulis apapun MILLENIALS INVESTING: "SMALL STEP FOR GREAT JOURNEY"

yang diinginkannya namun hal itu tidak dapat dilakukan karena adanya hambatan yaitu karena adanya keterbatasan yang diatur dalam UU ITE. Sehingga untuk mengatasi hal tersebut, ia berupaya untuk berhati-hati dalam memposting atau berbicara mengenai sesuatu yang sensitif agar tetap dapat menyampaikan pesan yang ingin disampaikan kepada pengikut melalui akun ini. 
Hambatan lain dalam langkah ini adalah dalam segi pemilihan konten. Ia memikirkan konten apa yang tepat untuk disebar di akun ini karena pembahasannya harus tepat sesuai dengan target publiknya dan tidak semua orang dapat menerima konten tersebut secara positif. Persepsi setiap orang berbeda-beda jadi dia harus melihat apakah konten itu perlu diposting atau lebih baik tidak. Karena postingan itu dapat dilihat banyak orang sehingga harus tetap berhati-hati. Pastinya konten-konten yang diunggah oleh pemilik akun memiliki tujuan baik untuk memberikan informasi dan edukasi baru untuk pengikut dan pengguna Instagram yang lain.

Oleh karena itu, Monica Devina mengupayakan agar postingan yang disebar dapat diterima dengan baik dan membantu dalam memberikan edukasi mengenai pelecehan seksual terutama informasi mengenai Catcalling. Akun ini bertujuan untuk hal baik oleh karena itu harus menghasilkan persepsi dan mendapat dukungan yang baik dari publik. Namun, jika ada masukkan mengenai konten yang diposting, itu dapat menjadi pelajaran baginya untuk lebih baik lagi kedepannya.

b. Hambatan dan upaya pada langkah interaksi

Hambatan yang terdapat pada langkah interaksi berasal dari sisi luar yaitu masalah negative comment yang masih menyudutkan korban serta terkadang ada banyaknya komentar dalam satu postingan menyebabkan pengelola akun sulit untuk membalas satu persatu sehingga ada beberapa komen yang bercerita mengenai pengalaman mereka belum sempat terbalas.

Upaya pada langkah interaksi adalah menegur dan memberikan pemahaman kepada orang yang mengirimkan komentar negatif namun jika sudah parah maka terpaksa harus memblokir akun pengirim komen negatif tersebut agar tidak bisa berkomentar atau melihat postingan akun @ dearcatcallers.id.

c. Hambatan dan upaya pada langkah aplikasi

Hambatan pada langkah aplikasi terjadi jika pengikut atau pengguna Instagram yang sudah membaca postingan masih belum paham sehingga tidak mendapatkan efek tertentu dan tidak dapat mengaplikasikan edukasi tersebut ke kehidupan mereka.

Upaya dalam langkah aplikasi adalah meningkatkan kualitas postingan dan mempertajam maksud pesan namun tetap pada pembahasan tema yang dibahas oleh akun ini agar semua orang dapat memahami pesan yang ingin disampaikan oleh akun ini.

Berdasarkan hasil penelitian yang telah dilakukan dan analisa, maka peneliti dapat menarik kesimpulan sebagai berikut:

Tujuan penelitian ini dilakukan adalah untuk mengetahui bagaimana akun Instagram @dearcatcallers.id dalam mengedukasi dan meningkatkan kesadaran mengenai Catcalling serta untuk menjawab pertanyaan penelitian mengenai hambatan dan upaya selama melakukan edukasi. 
Oleh karena itu, peneliti mencari tahu bagaimana mereka dapat mengedukasi dan meningkatkan kesadaran melalui pemanfaatan yang terdapat dalam fitur-fitur Instagram. Hal ini ditujukan untuk mengedukasi dan meningkatkan kesadaran mengenai isu Catcalling sehingga menghasilkan sebuah hasil yang berbeda-beda pada setiap individu melalui cara pengaplikasian informasi di kehidupan pengikut seperti lebih paham dan mengetahui informasi terbaru mengenai isu pelecehan seksual dan cara yang tepat untuk mengatasi Catcalling jika mengalaminya.

a. Fitur Profil

Fitur profil dimanfaatkan oleh akun Instagram @dearcatcallers.id dalam mengedukasi secara dasar mengenai apa itu Catcalling dan tujuan dasar akun ini melalui foto profil Instagram yag berupa logo sebagai simbol berisi pesan untuk melawan Catcalling, bio profil akun, dan kategori akun sebagai akun Instagram bisnis yaitu "gerakan" yang artinya melawan Catcalling.

b. Fitur Pengikut dan Mengikuti

Fitur Pengikut dan Mengikuti digunakan sebagai fitur yang menunjukkan bahwa orang-orang yang mengikuti akun ini memiliki ketertarikan akan isu pelecehan seksual dan Catcalling. Pengikut akun Instagram @dearcatcallers.id kebanyakan adalah wanita dengan hasil presentase sebanyak 83\% dan pria sebanyak 17\%. Pengikut akun tersebut kebanyakan berusia 18-24 dan 25-34 tahun dan fitur mengikuti digunakan untuk mengikuti akun-akun yang membahas mengenai tema serupa mengenai pelecehan seksual sehingga dapat bekerja sama jika ada informasi baru untuk saling posting.

c. Fitur Postingan Foto dan Video

Fitur ini dimanfaatkan oleh akun ini untuk menyebarkan informasi sebagai konten yang mengedukasi. Konten yang diposting harus tepat dan sesuai untuk dibahas agar pesan dalam konten postingan tersebut dapat tersampaikan dengan baik sehingga dapat memberikan edukasi dan meningkatkan kesadaran mengenai isu pelecehan seksual khususnya mengenai Catcalling.

d. Fitur Keterangan Postingan

Fitur keterangan postingan digunakan sebagai pelengkap untuk memperjelas postingan dan memberikan informasi edukasi berupa pesan atau opini kepada pengikut maupun pengguna Instagram yang lain.

e. Fitur Cerita Instagram

Fitur ini dimanfaatkan akun Instagram @dearcatcallers.id dalam upaya memberikan edukasi dan informasi mengenai pecelehan seksual terutama Catcalling dengan pesan yang lebih singkat dan padat. Namun, akun ini tidak terlalu sering dalam memanfaatkan fitur ini dikarenakan pemilik akun merasa bahwa fitur cerita Instagram terbatas dalam menyampaikan pesan tidak seperti saat memanfaatkan fitur postingan dan keterangan postingan. Semua kumpulan cerita akun ini terdapat di profil yang dapat dilihat kembali oleh pengikut maupun pengguna Instagram lainnya.

f. Fitur Like 
Fitur like termasuk salah satu bentuk interaksi yang terjadi dalam akun Instagram @dearcatcallers.id. Interaksi like merupakan sebuah umpan balik atau feedback dari pengikut akun tersebut yang menunjukkan bahwa mereka setuju dengan apa yang sudah diposting oleh akun tersebut.

g. Fitur Komentar

Pada fitur komentar, dapat terjadi interaksi dua arah antara audience dengan pemilik akun Instagram @ dearcatcallers.id. Balasan komentar yang didapat dari pemilik akun@dearcatcallers.id memiliki tujuan untuk meluruskan pemikiran pengirim komentar yang salah atau memberikan edukasi dan meningkatkan kesadaran akan isu yang dibahas dalam postingan. Namun komentar yang terdapat dalam postingan akun Instagram @dearcatcallers.id tidak selalu dibalas oleh pemilik akun karena banyaknya komentar yang ada dan ada beberapa komentar yang sensitif atau komentar tersebut memang tidak perlu dibalas. Lalu dari terjalinnya interaksi di kolom komentar, membentuk hubungan hipersonal yaitu membangun kesan positif diantara keduanya sehingga pengirim komentar atau pengikut merasa jadi lebih termotivasi dan dapat berani mengutarakan pengalaman dan pendapatnya jika mengalami Catcalling dan merasa bahwa informasi yang diposting oleh akun ini merupakan informasi yang tepat dan terpercaya.

Adapun hambatan yang ditemui pemilik akun serta upaya untuk mengatasi hambatan tersebut yaitu adanya keterbatasan dalam memposting dan berbicara mengutarakan opini karena adanya UU ITE serta dari segi pemilihan konten. Maka upaya yang dilakukan adalah mengupayakan agar dapat berhati-hati dalam memposting atau berbicara mengenai sesuatu yang sensitif agar tetap dapat menyampaikan pesan yang baik serta hambatan yang terdapat dari sisi luar yaitu masalah negative comment yang masih menyudutkan korban sehingga pemilik akun menegur dan memberikan pemahaman kepada orang yang mengirimkan komentar negatif dan hambatan dapat terjadi jika pengikut atau pengguna Instagram yang sudah membaca postingan masih belum paham sehingga tidak mendapatkan efek tertentu dan tidak dapat mengaplikasikan edukasi tersebut ke kehidupan mereka. Maka, upaya dalam langkah aplikasi adalah meningkatkan kualitas postingan dan mempertajam maksud pesan.

\section{Kesimpulan}

Berdasarkan hasil penelitian yang telah dilakukan dan analisa pada bab sebelumnya, maka peneliti dapat menarik kesimpulan sebagai berikut:

Tujuan penelitian ini dilakukan adalah untuk mengetahui bagaimana akun Instagram @dearcatcallers.id dalam mengedukasi dan meningkatkan kesadaran mengenai Catcalling serta untuk menjawab pertanyaan penelitian mengenai hambatan dan upaya selama melakukan edukasi.

Oleh karena itu, peneliti mencari tahu bagaimana mereka dapat mengedukasi dan meningkatkan kesadaran melalui pemanfaatan yang terdapat dalam fitur-fitur Instagram. 
Monica Elvira

Hal ini ditujukan untuk mengedukasi dan meningkatkan kesadaran mengenai isu Catcalling sehingga menghasilkan sebuah hasil yang berbeda-beda pada setiap individu melalui cara pengaplikasian informasi di kehidupan pengikut seperti lebih paham dan mengetahui informasi terbaru mengenai isu pelecehan seksual dan cara yang tepat untuk mengatasi Catcalling jika mengalaminya. 
Analisis Pemanfaatan Instagram @ Dearcatcallers.id Sebagai Media Untuk Membentuk Kesadaran Mengenai Isu Catcalling Terhadap Wanita Di Indonesia

\section{BIBLIOGRAFI}

Carr, Caleb T., \& Hayes, Rebecca A. (2015). Social media: Defining, developing, and divining. Atlantic Journal of Communication, 23(1), 46-65. Google Scholar

El-Yana, Korry. (2021). Perempuan dalam Bingkai Media. Indigo Media. Google Scholar

Florence, Agnes Grace. (2017). Hubungan pengetahuan gizi dan pola konsumsi dengan status gizi pada mahasiswa tpb sekolah bisnis dan manajemen institut teknologi bandung. Fakultas Teknik Unpas. Google Scholar

Herdiansyah, Haris. (2016). Gender dalam perspektif psikologi. Jakarta: Salemba Humanika. Google Scholar

Hidayat, Angeline, \& Setyanto, Yugih. (2020). Fenomena catcalling sebagai bentuk pelecehan seksual secara verbal terhadap perempuan di Jakarta. Koneksi, 3(2), 485-492. Google Scholar

Karimkhani, Chante, Connett, Jessica, Boyers, Lindsay, Quest, Tyler, \& Dellavalle, Google Scholar

Robert P. (2014). Dermatology on instagram. Dermatology Online Journal, 20(7). Google Scholar

Kotler, Philip, \& Keller, Kevin Lane. (2016). Marketing management (15th global ed.). England: Pearson. Google Scholar

Manovich, Lev. (2017). Instagram and contemporary image. Nova Iorque: CUNY. Google Scholar

Mattern, Joanne. (2016). Instagram. ABDO. Google Scholar

Miles, Jason. (2013). Instagram power. McGraw-Hill Publishing New York, NY. Google Scholar

Moreau, Elise. (2018). What is Instagram, anyway. Here's What Instagram Is All about and How People Are Using It [Online]. Google Scholar

Prihatiningsih, Witanti. (2017). Motif penggunaan media sosial instagram di kalangan remaja. Communication, 8(1), 51-65. Google Scholar

Shopiani, Bunga Suci, Wilodati, Wilodati, \& Supriadi, Udin. (n.d.). Fenonema Victim Blaming pada Mahasiswa terhadap Korban Pelecehan Seksual. SOSIETAS, 11(1), 940-955. Google Scholar

Steele, Jeanne R., \& Brown, Jane D. (1995). Adolescent room culture: Studying media in the context of everyday life. Journal of Youth and Adolescence, 24(5), 551-576. 
Monica Elvira

Google Scholar

Suliyanto, S. E., \& MM, Suliyanto. (2017). Metode Penelitian Kuantitatif. Google Scholar

Tuasikal, Rahmat Fitrah, \& Patria, Bhina. (2019). Role of Social Support and Self-

Concept Clarity as Predictors on Thesis Writing Procrastination. Journal of Psychology and Instruction, 3(3), 76-82. Google Scholar

\section{Copyright holder:}

Monica Elvira (2021)

First publication right:

Syntax Literate: Jurnal Ilmiah Indonesia

This article is licensed under:

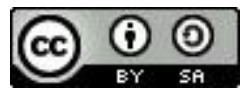

